\section{Science in the media}

Two contrasting looks at the place of science reporting in the media-one from each side of the Atlantic--have recently combined to provide an insight into the delights and pitfalls of science journalism, while showing how different these are in different countries. In Britain, the BBC Radio 3 programme "The Communicators" looked at science reporting in its issue of July 27. Here, the emphasis was squarely on the difficulties involved in getting a science story into the British national press at all.

The situation in this respect has deteriorated over the years, as the long serving science correspondent of the Daily Express recalled. With shortage of newsprint and a feeling that the public is to some extent disenchanted with hard science, it is all too easy for science journalists to fall into the trap of overdramatisation, at least in the eyes of the scientists. Several scientists interviewed in the programme expressed their concern about sensational reporting-one was distressed by a comment from one of the people making a documentary about typhoid that "we are in this game to entertain the public, not to educate them".

Such concern about sensational and inaccurate reporting is also felt on the other side of the Atlantic, to judge from an 'occasional paper' on Science in the Newspaper which has recently been published by the American Association for the Advancement of Science. But in many other respects the situation in the USA seems far different from that in Britain, giving the lie, perhaps, to any suggestion that sensational reporting arises because of the difficulty of getting any science story into print.

Science in the Newspaper itself is an odd mixture; contributions from award winning writers discussing their craft rub cheek by jowl with 'scientific' investigations of science reporting, complete with jargon and footnotes. Whether by accident or design, this neatly emphasises one point: the scientists certainly do need help in communicating their ideas to anyone outside a restricted circle of specialists.

Perhaps the most worrying contribution describes the result of a survey of what scientists think about science in the newspaper. The scientists had been asked to check for errors published in stories about their own work, and in more than 25 per cent of the cases they noted such damaging errors as misquotations, misleading headlines, omission of relevant information and excessive brevity.

But are the criteria scientists apply too strict, bearing in mind the audi- ence for which the articles were intended? When one respondent objected that in a report of the drop out rate of college students the first sentence said that more than half of the college students 'failed to obtain degrees' when it should have been qualified to add 'within four years', the criticism seems valid; but, we are told, the report in question did actually contain the important qualifications in its next sentence. That was not good enough for the scientist whose work was being described, but I would find it difficult to see his objection as one to worry the reporter who made the 'error'.

The point is, of course, that newspaper readers, by and large simply speak a different language from scientists, and that the journalist is literally in the position of interpreter. So many of the irritations felt by scientists are on the same level as the quibbling among multinational organisations about exactly how a French word in an agreement, say, should be translated into German.

This interpretative role is made abundantly clear in the most heartening anticle in Science in the Newspaper. The National Enquirer is an American weekly that was until a few years ago, we are told, a 'scandal sheet'. But now the Enquirer has changed its image, become a 'family newspaper' and just about quadrupled its circulation, to 4 million. And in that large circulation paper, science has a vital role.

In one recent 48 page issue mentioned, five per cent of the space was given up to science or medical stories. The treatment of these stories is dramatic, and successful in reaching a wide audience who respond with floods of letters. Not all the scientists whose work makes the pages of the Enquirer are pleased-Dr Sol Spiegelman, of Columbia University's Institute of Cancer Research, is quoted in Science in the Newspaper as being particularly unhappy about the treatment he received from the Enquirer's reporters.

But you can't please all the people all the time, and if a paper like the Enquirer can, by and large, encourage its readers to accept science as a valuable part of modern society which deals with problems that are relevant to the man in the street, the science journalists are doing their job. The success of the Enquirer's science policy ought to make some British popular newspapers rethink their attitude to science; the scientists might not always approve of the result, but then, nonscientists do not always approve of the activities of scientists.

The message from both of these slightly narcissistic looks in the mirror emphasises a feeling which already exists in both the USA and the UK. Science today must be relevant to the problems of today, and what is more it must be seen to be relevant.

JOHN GRIBBIN

\section{Easy listening science}

Over the past few weeks Saturday morning listeners to BBC Radio 4 have been having a taste of up to the minute reports from the scientific world. "Science Now", as its title suggests, has been keeping its audience abreast of the latest developments in science and techniques involved in anything from building a skyscraper from the top downwards to the possible hazard to the public from the development of new strains of mutant cells.

The BBC's radiophonic workshop provides a snappy piece of introductory music which sets the tone for a tightly packed programme of comment, interview and discussion. The presenter, Brian J. Ford, manages to maintain the tempo throughout, and it is this which seems to make the programme such easy listening.

Each thirty minute programme can cover a range of scientific topics acceptable both to working scientists and to the man in the street with an interest in science. When 'test tube babies' hit the headlines recently, "Science Now" covered the subject and brought out the implications in non-sensational terms. As Brian Ford said, the work represents "an interesting development, but not by any means a terrifying prospect".

In the same programme the question of how massive the Universe is and the eventual slowing down of its expansion, was discussed. But as seems inevitable in any science programme today, medical items receive a good share of attention. Audience response indicates the understandable popularity of medicine, but it does seem a little unfortunate that this sometimes serves to divert a large proportion of the very limited air time available for science (see Nature, 250, 362; 1974) away from 'hard science'.

Still, a complete edition of "Science Now" was devoted to applied science and included oceanography, crop irrigation, building methods, cancer research and an exhibition to celebrate the discovery of oxygen 200 years ago.

Where the programme differs from some of its predecessors is in the amount of comment provided by the presenter, either with or without contributions from a second party. This is a significant and worthwhile development, since often the caution of a 